\title{
MESTRE DADO E DEUSA MINERVA UMA PERFORMANCE DE UMBIGADA
}

\author{
Eleonora Gabriel
}

A Companhia Folclórica do Rio-UFRJ realiza o evento Encontro com Mestres Populares na UFRJ. Muita festa e, também, oficinas, discussões e construção coletiva de carta-documento com reivindicações. Já participaram vários grupos, entre eles, o Batuque de Umbigada de Piracicaba, Tietê e Capivari, SP. Nossos amigos batuqueiros construíram o tão sonhado Barracão, um lugar da memória dos ancestrais e brincantes de hoje. Fomos convidados para a inauguração. Mestre Dado avisou: "Firma as pernas que nós vamos dançar muito." E assim foi. Mestre Dado e Deusa Minerva (símbolo da UFRJ) brincaram e brincarão para sempre, numa bem firmada umbigada. [Abstract on page 246]

CULTURA POPULAR, UMBIGADA, UNIVERSIDADE, FESTA. 
A Companhia Folclórica do Rio-UFRJ há 23 anos tem a missão e muito prazer de levar à UFRJ a sabedoria popular. Nossa alegria é sermos intérpretes da cultura tradicional brasileira e dançar, tocar, representar e brincar muito com todo esse potencial que é nosso. Para isso vamos a campo aprender com mestres populares. Desde sempre nossa presença, naturalmente, levou as comunidades a uma reavaliação daquela expressão, muitas vezes desvalorizada em seu próprio habitat. Sentimos, então, que deveríamos cuidar mais desse encontro e realmente contribuir com essas pessoas que levam toda uma vida ensinando, incentivando, criando e recriando arte, através das performances que a herança Ihes deixou. Muitas são as questões. Desenvolvemos ações na Educação e na Arte, junto aos alunos da Escola de Educação Física e Desportos e Escola de Dança da UFRJ e da rede municipal de ensino, a projetos sociais e a grupos tradicionais. Em 2007 criamos e tivemos condições de realizar o I Encontro com Mestres Populares na UFRJ, com o objetivo de trazer para dentro da Universidade grupos tradicionais de danças e folguedos da Região Sudeste do Brasil. Além de oficinas oferecidas pelos mestres, abertas ao público em geral, todos os presentes participaram de palestras de vários estudiosos sobre a situação do mestre popular e seus grupos, perante as leis governamentais e a sociedade em geral. Nas duas edições já estiveram conosco os grupos Reisado Flor do Oriente de Duque de Caxias e Manjedoura da Mangueira; Jongos da Serrinha, do Salgueiro, de Angra; Bumba meu Boi de Parada de Lucas; Boi Pintadinho, Mineiro-pau e Caxambu de Santo Antônio de Pádua; Cirandas de Tarituba-Paraty, Fado de Quissamã - todos do Estado do Rio de Janeiro - e vários mestres das bandas de congo do Espírito Santo; congado mineiro Moçambique Pena Branca e Batuque de Umbigada de Piracicaba, Tietê e Capivari - São Paulo, inspiração deste trabalho.

No I Encontro, preenchemos com nossos convidados um projeto de incentivo recém-lançado pelo Ministério da Cultura - MinC, por intermédio da Secretaria de Identidade e Diversidade Cultural. Para nossa alegria, vários grupos foram agraciados com o Prêmio Mestre Duda para as Culturas Populares. Nossos amigos batuqueiros construíram o tão sonhado Barracão, um lugar da memória dos ancestrais e brincantes de hoje, um lugar para reunir, preservar e vadiar. Fomos convidados para a inauguração da Casa do Batuque de Umbigada Fogo Verde (nome de um antigo mestre batuqueiro), no dia 25 de maio de 2008. E fomos. Este ensaio conta esse encontro, essa umbigada de alteridades que vira diversidade nos corpos de universitários e pedreiros, empregadas domésticas, trabalhadores agrícolas, todos reis e rainhas neste dia.

Mestre Dado (Figura 1), Osvaldo Ferreira Merches, será o contador desta história do encontro e da performance do Batuque de Umbigada da região, único grupo que havia na época. Nascido em 6 de outubro de 1931, em Piracicaba, foi pedreiro, mestre de obras, jogador e juiz de futebol. Há muitos anos é mestre do grupo Batuque de Umbigada Fogo Verde de Piracicaba, Tietê e Capivari. Selecionamos vários trechos de entrevistas, colhidas durante os três dias que estivemos juntos, "acampados" no Barracão - a casa do grupo, em Piracicaba, São Paulo - e aqui reproduzidas minimamente editadas, sem, contudo, comprometer o jeito natural de o Mestre se expressar. Juntamos nessa festa algu- 


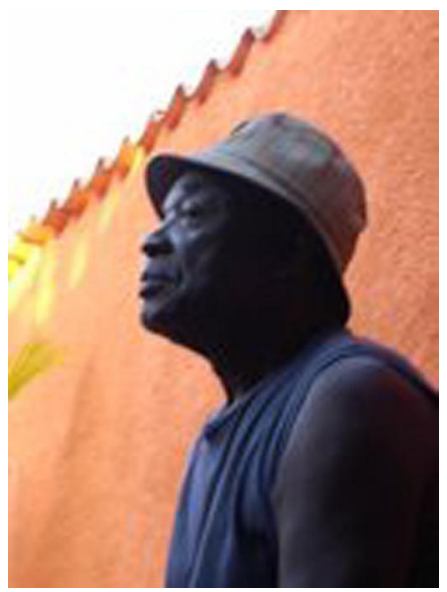

Figura 1: Mestre Dado

Foto de Jacqueline Barbosa

Acervo da Companhia Folclórica do Rio-UFRJ

mas considerações de estudiosos e próprias sobre os assuntos pertinentes, ainda em fase de construção, tudo entremeado com o perfume da poesia das modas (canções) batuqueiras que apreendemos nessa experiência de maravilhamento.

$\mathrm{O}$ apito toca, todos prontos.

\section{TÁ NA HORA. TÁ NA HORA / TÁ NA HORA DO BALÃO SUBIR / VAMOS FAZER BONITO / PIRACICABA, TIETÊ, CAPIVARI. ${ }^{1}$}

Cascudo (2001, p. 135) conta, no livro Made in África, que batuque era nome dado pelos viajantes portugueses na África "...aos tambores e aos bailes de pretos. Batuque é a coreografia e o instrumental percussor". Cita, também, relatos do português Alfredo Sarmento que se refere a uma dança em roda e com umbigadas, denominada batuque, no Congo e em Angola. O termo genérico dominou o território brasileiro. Tinhorão rela1 Todas as modas citadas neste artigo foram colhidas no Barracão Batuque de Umbigada Fogo Verde, em Piracicaba, São Paulo, nos dias 28, 29 e 30 de maio de 2008, sem compositores declarados. ta que tinha o nome de batuques, no Brasil, uma diversidade de práticas religiosas, danças rituais e formas de lazer, e que só no decorrer do século XVIII, quando "as autoridades começaram a distinguir nessas reuniões à base de danças, cantos e ritmos de percussão o que era culto religioso daquilo que constituía apenas ritos da vida social ou mera diversão para os escravos, os campos começaram a ser delimitados" (2008, p. 55). Bem mais tarde foram identificados como coco, lundu, sabão, samba, etc. Vários estudiosos ressaltam o preconceito das classes hegemônicas em relação a essas e outras manifestações afro-brasileiras durante muito tempo (em alguns lugares, até hoje), e o resguardo das próprias comunidades negras, com o objetivo de manutenção de códigos e segredos da cultura do grupo.

Segundo Mestre Dado,

O Batuque é tudo. Não sei o que é esse tudo, é muito. Eu fico bastante feliz. Meu pai era de Ribeirão Preto; mamãe, daqui mesmo. Ele contava que os negros para trás sofreram muito aqui. Dizia que as pessoas eram separadas dos 
filhos e ficavam girando em volta de uma árvore, rezando e chorando, querendo saber onde estavam seus parentes. Sofreram muito!

Essa recordação concreta e simbólica do Mestre logo nos faz lembrar Baobá, a árvore-mãe, árvore sagrada africana trazida para o Brasil por negros escravizados. Alguns pesquisadores relatam que, antes de embarcarem nos navios negreiros, esses homens e mulheres giravam em volta da árvore para esquecer sua cultura e histórias.

Segundo Edison Carneiro (1981, p. 29), os povos africanos que foram arrancados de suas terras como escravos podem ser divididos em duas categorias, segundo sua procedência: negros sudaneses e negros bantos. Os sudaneses, vindos da zona do Niger, na África Ocidental, foram levados para a Bahia, de onde se espalharam para o Recôncavo e foram trabalhar nas lavouras. Dias (2001, p. 865) afirma que os sudaneses vieram dos territórios que hoje correspondem à Nigéria e ao Benim e foram utilizados também em trabalhos domésticos nas capitais do Nordeste brasileiro. Os bantos, grupo que provavelmente deu origem ao batuque de umbigada paulista, pertenciam a várias etnias do Congo, de Angola e Moçambique, e moveram, desde o século XVII, os engenhos de açúcar do Nordeste; no século XVIII extraíram ouro e diamantes das Minas Gerais e no XIX plantaram e colheram no Sudeste o tão apreciado café.

Cascudo (1983, p. 103) registra que cerca de 50 milhões de homens e mulheres, falando 274 línguas e dialetos aparentados, foram retirados das regiões central e sudeste da África e distribuídos por vários lugares do mundo. "Banto é família linguística e não etnográfica ou antropológica." Relata que quando foram enviados ao Brasil e toda a América do Sul os bantos tinham elementos fortes da cultura árabe "lendas, mitos e tradições orientais vieram nas suas memórias (...) e tinham predileção viva pelo canto e pela dança coletiva... e a alegria". Conta Mestre Dado:

Meu pai tinha uma religião fechada, mas ia ver o batuque. Já mamãe gostava do negócio. Crianças não podiam participar. Eles brigavam, aí a gente afastava um pouquinho e voltava de novo. Com meus nove, dez, 11, 12 anos eu ia sozinho; eu precisava ver aqueles homens dançando. Achava muito bonito. Muito alegre. Não parei mais e todo batuque que tinha eu estava. $O$ tronco do batuque é Piracicaba.

\section{O RIO DE PIRACICABA VAI JOGAR ÁGUA PRA FORA / QUANDO EU PASSO NA PONTE / DÁ VONTADE DE CHORAR / O NOSSO RIO TÁ SE ACABANDO /O NOSSO RIO VAI SE ACABAR}

Piracicaba em tupi-guarani quer dizer "lugar onde o peixe para". Trata-se de referência às grandiosas quedas do rio Piracicaba que bloqueiam a piracema. No final do século XVIII Piracicaba se desenvolve com base na navegação do rio e no cultivo da cana-de-açúcar, ignorando a chegada do café no oeste paulista, região em que se localiza. Devido ao cultivo da cana, a área torna-se um dos principais polos de escravidão, com grande presença de escravos e negros libertos. Em 1881 é fundado, às margens do rio Piracicaba, o Engenho Central, que se tornaria o maior engenho de açúcar do Brasil nos anos seguintes. Hoje é ponto turístico em que acontecem eventos culturais de vários ti- 
pos - foi primeiro lugar que Mestre Dado nos apresentou - e faz parte do Complexo Museu da Águas.

Eu era cabeceador de sacos de açúcar. Achava bonito aquele monte de saco até o teto, empilhado, e resolvi ser isso; mas não guentei nem 15 dias. A cabeça esquentava muito, não dava não. Saí corrido. E voltei para trabalhar fazendo prateleiras no subterrâneo para a telefônica (senhor Osvaldo, antigo trabaIhador do engenho).

Na década de 1880 Piracicaba começou a substituir o trabalho escravo pelos imigrantes assalariados: portugueses, italianos e sírio-libaneses, e Mestre Dado observa:

Nossa! Aqui tem muito italiano e sírio. Eles, quando sabe que o batuque está bom, eles querem brincar muito, tomar conta, vai tudo. É mais fácil vir eles do que... assim que nem eu para a festa de batuque. Noutro dia, fiquei até com vergonha. Veio uma moça pediu licença para sentar no tambu ${ }^{2}$, outra pediu para cantar, um rapazinho pediu para tocar quinjengue, o 2 Nome do tambor principal, que também dá nome à performance. outro, a matraca. A mulher cantou moda, e eles tocaram pra gente dançar. Graças a Deus! Os patrícios... já falei, vai chegar uma época que nós vai ficar parado, e eles vão mandar ver. A minha gente está querendo parar (...) enquanto o pessoal vem vindo. Eu estou achando assim, que outra turma venha. Eles falam: Oiá eles dançando tambu. Que que tem? Não tem nada demais eles dançando batuque.

Essa convivência não foi sempre tão tranquila. A Revista Eletrônica do Arquivo do Estado de São Paulo conta que nas décadas de 1940 e 1950 surgiram vários clubes frequentados pela população negra paulista - Sorocaba, Porto Feliz, Piracicaba, etc. -, que não podia entrar em alguns espaços sociais. O Mestre comemora:

Hoje, dança tudo junto, mas antigamente era difícil. Não é que não podia entrar em outro lugar. Não dizia não pode entrar. Mas... você sabe, a diretoria não gostava. Eu mesmo não arrodeava. O Clube Treze de Maio é bom, é coisa de nego, é nossa casa. Eu morei no Treze por 12 anos, minha esposa zelava lá. A gente sempre fez festa lá; tinha barraca disso, daquilo, vendia quentão, pinga. Um terreno grande bem no Centro da cidade. Aí tiveram que vender uma parte para fazer o prédio. Dança em cima e embaixo, muito bom para se divertir; é dos negro mesmo, casa nossa. Ali faz baile no dia 13 de maio, faz forró. Esse ano fizemos festa lá . Fiquei bobo de ver aquela montoeira de gente, não tinha baile nem nada. Foram ver o batuque. Ver batuque não tem prejuízo nenhum, a gente fica dançando, e o povo vendendo a cerveja deles, vendendo sanduíche deles, e nós lá, cantando. Depois tem o baile, baile bom, toca tudo. Nego tem que ir na estica, não pode (...)ir de qualquer jeito. Esse ano eles me deram um pedaço de vidro escrito alguma coisa, homenageando.

\section{ACABOU A ESCRAVIDÃO, ACABOU A ESCRAVIDÃO / MAS QUE BELEZA / NEGRO COMIA NO COCHO, NEGRO COMIA NO COCHO / AGORA COME NA MESA}

Há na cidade um busto em homenagem a André Ferreira dos Santos, o dr. Preto, que salvou a vida de grande parte da população de Piracicaba no combate à gripe espanhola. Este ano Mestre Dado foi homenageado com um diploma que, devidamente en- 
quadrado, fica na sala de sua casa. Em pesquisas sobre a cidade, descobrimos que lá existe um Centro de Documentação da Cultura Negra, do qual, entretanto, Mestre Dado nunca ouviu falar. Durante 30 anos, de 1844 a 1874, manteve-se na cidade o quilombo Corumbataí, importante foco histórico de resistência. O pesquisador Noedi Monteiro (2008) informa que era muito grande e desafiou a milícia e tropas do governo. Existe na cidade um reduto chamado Vila África com maioria de moradores afro-descendentes. Piracicaba foi a terceira maior população escrava da província de São Paulo. Muitas são as histórias. Hoje, Piracicaba é um dos maiores polos produtores de açúcar e álcool do mundo, além de contar com importante centro industrial e diversas universidades de renome. Monteiro $(2008$, p. 2) complementa: "Piracicaba acabou se postulando fortemente como uma cidade de descendência afro-brasileira (...) e já tivemos o privilégio de fazer parte do quadrilátero da população negra do estado de São Paulo, que comporta as cidades de Piracicaba, Tietê, Limeira e Capivari." Outra referência importante é a Igreja de São Benedito que pertenceu à Confraria de Nossa Senhora do Rosário dos Homens Pretos, também atuante como foco de resistência: comprava alforrias e abrigava cultos das religiões afrobrasileiras. Diz o Mestre:

O meu gosto era desfilar no dia de São Benedito! Ver o batuque na frente ou do lado da igreja. Aí falaram com o padre e o ministro, que aceitaram. Depois pediram pra gente voltar para o ano, porque achou muito bonito. Mas no ano seguinte foi só a congada, a gente gostou de ter ido a congada, mas depois ele ficou perguntando cadê os tambores. Eles fala, mas não faz.

Paulo Dias afirma que na crônica histórica brasileira da colônia e do império as danças de terreiros dos escravos negros, designadas batuques, são qualificadas como diversão "desonesta" em contraponto com a "honesta", que tinha cunho religioso, adaptada às crenças do catolicismo, como as congadas e outros reinados. As primeiras eram entendidas como representação de possíveis rituais pagãos e que atuavam como fermento para a desordem social e revoltas. Será que em Piracicaba esse pensamento ainda perdura? No início dos anos 50, o batuque de umbigada foi proibido por ser imoral. Os participantes foram fotografados, fichados e até presos pela polícia. A classe média dizia que o batuque era bom no mato, na roça, não dentro da cidade. Quando pesquisamos no site oficial de Piracicaba, constatamos a citação das festas de imigrantes sem que seja mencionada a festa do dia 13 de maio.

\section{EU MORO EM CAPIVARI / GOSTO MUITO DESSA TERRA / SÃO JOÃO QUE ME PERDOE / O QUE VOU CONTAR AQUI / TEM QUE ACABAR PRECONCEITO / DENTRO DE CAPIVARI.}

Mestre Dado e seu grupo, composto por moradores das três cidades - Piracicaba, Tietê e Capivari -, brincam nessa festa do dia 13 de maio e quando são convidados para participar de eventos. As prefeituras locais não mantêm o grupo. Na inauguração do Barracão, a prefeitura de Capivari mandou um ônibus com os integrantes daquela cidade. Mestre Dado foi buscar alguns batuqueiros de Tietê de carro, e os demais vieram de condução de linha. Para nossa surpresa, poucos dias depois de nossa visita, o jornal de Ca- 
(PJORNAL DE PIRACICABA 睓

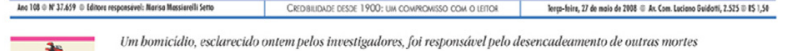
Vingança motivou série
de execuções, afirma DIG

dos personatoras

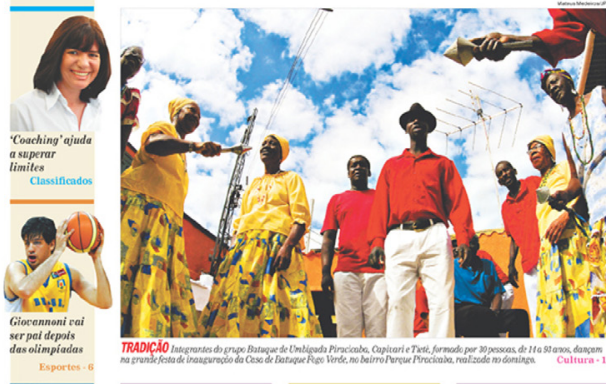

Figura 2: Jornal de Piracicaba (primeira página), 27 de maio de 2008

Acervo da Companhia Folclórica do Rio-UFRJ

pivari informou que a partir daquele momento a Secretaria de Cultura local estaria oferecendo oficinas de batuque para o público em geral. O Jornal de Piracicaba, a nosso pedido, esteve na festa de inauguração do Barracão e, no dia seguinte, o grupo Batuque de Umbigada Fogo Verde estava na primeira página, fato inédito. A reportagem relatava o acontecimento e mencionava nosso incentivo (Figura 2).

Mais uma vez em campo, percebemos que nossos focos de pesquisas são "pessoas reais", com conflitos na comunidade em que vivem e entre os integrantes do grupo, o que coloca o pesquisador que se pretende integrar aos viventes da manifestação pesquisada em situação muito delicada, de constante avaliação de suas ações. Esse é, e será sempre, um grande desafio nessa parceria. Como entender uma performance tão intensa e contemporânea sem a entender como pertencente a um ambiente histórico-social?

Homens e mulheres de todas as idades criam performances - até para poder entender a própria vida -, representação e reflexão de ideias, e consequente criação cênica do que se vive e do que se quer dizer, marcando identidades. Um misto de esquecimento e lembrança que nos faz performáticos, em processo de completude, executantes de um "ritual em ação", expressão usada por Victor Turner, citado por Barbosa e Teixeira (2000, p. 124). Duvignaud (1970, p. 62) se refere à atitude estética da Arte encontrada em diversos tipos de sociedades e definida como "ilustração voluntária da vida cotidiana"; tratase da ideia de um grupo mirar-se num espelho,

um instrumento de exaltação, de contentamento, de conforto, de solidificação e de confirmação na sua própria existência, no seu destino (...) uma sublimação pessoal da vida particular, do estabelecimento de uma proteção que dá ao grupo a certeza de se manter mesmo (e sobretudo) quando ameaçado por outros grupos ou, simplesmente, condenado pelo tempo. 
Sob forma de festa, a "realização pela representação" conserva, sob todos os aspectos, as características formais do jogo. Huizinga (2001, p. 12) aborda o jogo como atividade temporária, que tem finalidade autônoma e se realiza tendo em vista alguma satisfação que consiste nessa própria realização - um intervalo em nosso cotidiano; ornamento da vida. Sendo assim, observa o autor, "torna-se uma necessidade tanto para o indivíduo, como função vital, quanto para a sociedade, devido ao sentido que encerra, a sua significação, o seu valor expressivo, as suas associações espirituais e sociais, em resumo, como função cultural".

A festa ou culto, como um jogo humano, dá conta de todo tipo de ideais comunitários. Um universo próprio de valor temporário, com efeitos que não cessam depois de acabado o jogo. “(...) seu esplendor continua sendo projetado sobre o mundo de todos os dias, influência benéfica que garante a segurança, a ordem e a prosperidade de todo o grupo até a próxima época dos rituais sagrados" (HUIZINGA, 2001, p.17). Um tesouro a ser conservado pela memória.

Graziela Rodrigues (1997, p.19-20) menciona a memória dos afetos, os corpos que se movem por forte lembrança ancestral. A cada momento do presente o passado é resgatado e ao futuro interliga-se, resistindo às dificuldades quando o corpo junto com o "outro" - o da memória afetiva - realiza o movimento que se duplica pela força da manutenção. A dança exerce a função de revivificar a memória, construindo-se a partir dos próprios sentidos da festividade. A emoção, o arrebatamento perante os fenômenos da vida e da natureza que inspiram a capacidade criadora e elevam o homem à expressão poética e à arte. À performance.

Mestre Dado explica como se constrói a performance do batuque.

A primeira coisa são os tambores. A gente tem que encachaçar eles e botar perto do fogo. Você sabe, o couro tem que esticar para sair um som bom, para ficar bonito. Esses tambores a gente cavuca com formão um tronco de jaboticabeira ou cedro, ou eucalipto, ou jequitibá e taca fogo, cavuca mais, bota fogo, cavuca mais e mais até abrir tudo, e bota num lado couro de cabrito veIho ou bezerrinho. Esse tambu [tambor grande com mais ou menos um metro e meio de comprimento], se eu tenho quase 80 anos, esse tambu tem mais de 100. É muito antigo, depende do zelar dele. Ninguém sabe como ele apareceu no Treze. Quanto mais bate na virada do couro, nas pontas, o som fica mais alto , mais aberto, no meio é mais grave, o tocador fica livre para tocar, sem perder o ritmo. O quinjengue [tambor pequeno em forma de cálice] também tem que dar cachaça para ele, na cabeça dele e botar para esquentar. Esse fui eu que fiz. Era um pilão muito antigo, e tome de cavucar. Cavuquei muito! Quando os tambores estão falando bonito, vamos começar. Um senta no tambu [que fica deitado no chão; o tocador senta com as pernas abertas, mais próximo do couro onde vai tocar], outro pega as matracas [dois rolos de madeira pesada de uns $50 \mathrm{~cm}$ ] para dar cacetada (...) perto do pé do tambu. Aí encosta o quijengue no tambu, no espaço entre o tocador do tambu e o matraqueiro. Aí está pronto. Eu apito para formar as fileiras, uma de homem, outra de muIher, uma em frente a outra. 
No tambu cada um toca de um jeito, mas no ritmo, sabendo que tem que acompanhar a moda. Quem manda é a moda. Alguém puxa a moda, a música. Todo mundo repete os versos. Só toca o tambor depois que a moda subir! A moda sobe quando todo mundo já pegou (...) Eu toco o guaiá ${ }^{3}$ (...) quando está tudo dentro do comando. Aí a matraca entra e manda muito, tem uma voz muito alta. O quinjengue responde, e entra o tambu. E junta tudo, senão a moda não sobe. Eu já apitei e parei várias vezes, e o pessoal perguntou por quê. Porque estava errado. O tambu estava fora do tempo.

Frigerio (2003) observa o caráter multidimensional (batuque-dança e canto) e participativo da performance afro-americana e ressalta a conversação entre as artes integradas na ma-

3 Chocalho de alumínio em forma de cone, muito utilizado em rituais religiosos de candomblé $e$ umbanda. Algumas batuqueiras também usam para chamar atenção do batuqueiro, "fazer um gracejo", dizem elas.

nifestação. Vimos no depoimento do Mestre a interação entre

o solista que puxa a moda e o coro, que é o conjunto de todos os participantes. Na festa de inauguração dona Anecide Toledo, de Capivari, foi a puxadora da maioria das modas, sendo várias de sua autoria. A voz forte dessa negra, que deve ter completado mais de 70 primaveras, encantou todos, e ela é considerada a Rainha do Batuque. Mestre Dado conta que as mulheres, antigamente, só podiam dançar e fazer coro. "Hoje a mulherada está até tocando tambu e quando senta não levanta por nada. Eu acho muuito bom" [o mestre entoa esse muito com muuita propriedade e charme, e nós, da Companhia, adotamos esse jeito de falar].

Voltando aos diálogos, podemos notar que os timbres dos tambores e matracas se complementam, sendo a tríade sonora agudo, médio e grave muito comum em ritos afro-brasileiros. "Debido a su ejecución polirrítmica, los tambores mas que tocar juntos, deben responderse uno al outro, deben conversar" registra Frigerio (2003, p. 58), que ressalta também a resposta instrumental ao solista do canto, como vimos aqui.

Quando balança assim o guaiá é que a moda está boa, vamos dançar. Sempre foi assim desse jeito. Forma as duas filas. O homem sobe cantando. ${ }^{4}$ Quando o homem volta de costas, vem a nega aqui cumprimentar. Ela desce. É bonito... elas que nem uma borboleta se balançando. Elas voltam um pouco, e aí, quando nós sobe de novo, já está batendo. E toma umbigada! Você não vai deixar ela cair, ela também não vai deixar o nego cair; aí, se a dama é boa, muitas vezes bate 4 Os homens vão, todos juntos sem perder o alinhamento, até a fila das mulheres para um cumprimento.

50 Mestre fala: "Brigadão". quatro umbigada, depois dá vergonha, mas é três só.

Agradece a dama ${ }^{5}$ e aí cada um, dama e batuqueiro, pode ir bater com quem quiser. Quando o mestre apita, para tudo. Quando a moda acaba, começa outra, e começa tudo de novo.

Uma delícia! Só vivendo. As palavras não conseguem descrever essa sensação. 0 encontro do masculino com o feminino de forma elegante, charmosa e gostosa. Um galanteio, um namoro, concreto, uma conversa. A umbigada fica tatuada no corpo da gente. Ainda mais coletiva! Todos se umbigam quase ao mesmo tempo com seus pares e de- 
Figura 3: A borboleta e a companhia

Foto de Eleonora Gabriel Acervo da Companhia Folclórica do Rio-

UFRJ

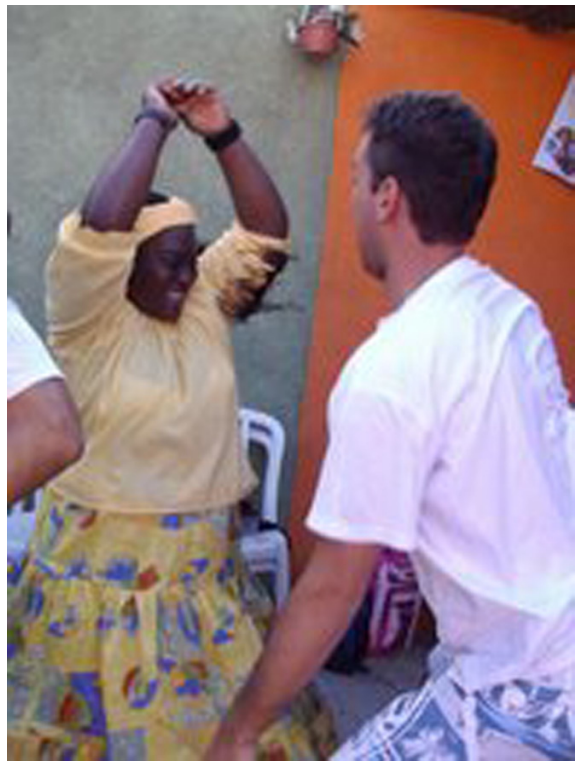

pois com quem quiser e conseguir seduzir, no sorriso e no bailado das saias longas e rodadas. Como borboletas, que os homens vão tocar lá no alto e que também descem para encantar o outro. A ancestralidade é a brisa que faz o balanço dos batuqueiros. Todo mundo fica igual, tudo muito sensual, pura poesia (Figura 3).

E a umbigada?

"One of the essential parts of most natives dances in Angola is the smacking of stomachs (...)" (uma das partes essenciais da maioria das danças nativas em Angola é a batida de barrigas), relata Heli Chatelaine em texto editado em 1894, citado por Cascudo (2001, p. 136), que continua afirmando que semba é umbigo em quimbundo e que no $D i-$ cionário Kimbundo-Português de A. Assis Júnior lê-se massemba - umbigada (na dança). Afirma que a umbigada é uma "permanente" banto e não sudanesa e que, nos bailados que viu em Angola e Moçambique, a umbigada ocorre como nos batuques de São Paulo, sem ser um chamado para substituição do bailarino-solista, como em vários lugares no Brasil, mas uma provocação cordial. Vários estudiosos mencionam a cerimônia de lembamento, referente à virgindade, dos jogos amorosos e sexuais dos casamentos africanos. Um rito de procriação, afirmam (Figura 4).

Dona Odete, uma das batuqueiras mais antigas, chamada por todos de Mãe África, moradora da Vila África de Piracicaba, diz que muito romance já aconteceu no batuque, pela dança da umbigada: "la lá, umbigava, gostava, voltava, e se combinava dava namoro e até casamento". Dona Esmeralda, outra linda borboleta, expressa: "Eu fico feliz quando dou uma umbigada; é tão gostoso, e assim estou lembrando, para todo mundo, dos meus avós e todos os nossos ancestrais". Esmeralda estava acompanhada da mãe, 


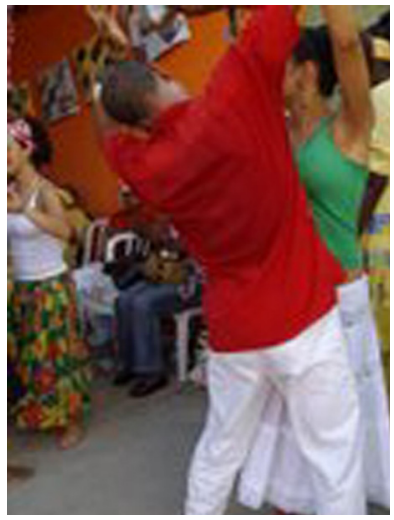

Figura 4: A umbigada

Foto de Eleonora Gabriel

Acervo da Companhia Folclórica do Rio-UFRJ

da filha e da neta de nove anos, todas batuqueiras orgulhosas de estar ali representando quatro gerações de mulheres que brincam o batuque juntas.

Mestre Dado conta que, por causa da umbigada,

antigamente tinha que dançar lá no matão, porque o homem não queria. Em Tietê quando tinha festa de batuque, tinha que ser lá embaixo, porque o povo não estava gostando daquele tipo de dança, era desrespeitosa. Não era desrespeitosa. Batuque é muito bonito. Umbigar é o meu respeito que estou dando pra aquela batuqueira. Vou passar isso para todos os batuqueiros: o meu respeito para aquela batuqueira. A minha neta, quando vem, eu bato com ela, o que que tem? Antes dizia que não podia umbigar com parente, tem até uma moda assim:

SEU COMPADRE COM COMADRE / PRECISA TER MUITO RESPEITO / ONDE DORME O COMPADRE / OUTRO NÃO PODE DEITAR / QUANDO MORRE ESSE COMPADRE / O OUTRO VIRA BITATÁ.

"Essa moda já vem lá de baixo. Do tempo que os nego veio era bom mesmo. Bitatá quer dizer que é o diabo, coisa que está chegando ali perto e vai destruir tudo." Hoje a netinha de Esmeralda pode dançar, mas o Mestre fica de olho.

Percebemos que os dançarinos têm de se deslocar, ou bater os pés, contando três tempos e uma pausa, o que dá a cadência da dança e define o momento de umbigar. Dada uma umbigada, os próximos três tempos e uma pausa são livres, cada um tem um jeito de fazer. Alguns homens vão até o chão, como uma queda. Homens e mulheres podem fazer no terceiro tempo o cruzamento de uma das pernas diante da outra, mudando levemente a direção do corpo. Quem quiser pode girar 360 ou 180 graus. Ou simplesmente balançar, ou criar outro meneio, o importante é no próximo compasso, no momento preciso da umbigada, todos estarem batendo - diálogo entre o dançarino e o tambor e entre os batuqueiros que bailam. As modas, que dão o tom da brincadeira, também podem ser improvisadas e, muitas vezes, motivadas por fatos que estão acontecendo com dançarinos naquele momento, como sugere também Frigerio (2003), observando as performances afro-americanas. Mestre Dado lembra: “Eu fiquei louco no Rio de 
Janeiro quando vi aquele cordão, quando aquele bando de gente começou a dançar. Fiquei emocionado, parecia o meu batalhão. Eu falei, para um pouquinho, são só três umbigadas, vamos começar de novo."

\section{EU NÃO SOU FOGÃO PRA FICAR DENTRO DE CASA / HOJE EU VOU SAIR LARGANDO BRASA / ME LARGA MEU BEM UM POUCO / PORQUE SENÃO VOU ACABAR FICANDO LOUCO.}

No Encontro com Mestres, eu e a dona Anézia, ${ }^{6}$ a gen-

6 Esposa do Mestre que registra tudo num diário do grupo e organiza todas as apresentações. te ia às oficinas para aprender. Aprendemos outras danças e que a gente tem que cuidar e saber quem é esse povo que vem aqui faz filme, grava e não mostra nada pra gente depois, não dá nenhuma notícia. Tudo tem que procurar saber. Eu já vi a gente na tevê, mas ninguém mandou pra gente.

Tivemos a preocupação, durante o I e o II Encontro com Mestres Populares na UFRJ, de informar os grupos sobre seus direitos enquanto portadores da cultura popular e o cuidado que devem ter em relação a pessoas que os abordam. Vários grupos, o Batuque incluído, reclamaram dessa falta de ética de alguns pesquisadores que vão aos lugares, realizam documentários, CDs e nada devolvem às comunidades. Essa questão ainda é muito recorrente na relação pesquisador/pesquisado. Junto com os grupos elaboramos cartas com as reivindicações pontuadas e divulgamos ao Ministério da Cultura e instituições do governo estadual e municipal. Estamos, em 2010, organizando a terceira edição do evento, que será patrocinada pelo MinC e reunirá grupos de outros estados.

Cascia Frade (2006, p. 13) observa: "A abertura dos vetustos portais de organizações acadêmicas às expressões populares é interpretada pelos artistas populares como valorização, aceitação, legitimação de seu saber, conferindo status." E complementa: para a universidade, acolher o conhecimento que se instaura distante dela soa como oportunidade de repensar suas práticas, de assumir uma postura crítica frente à busca do tão propalado "conhecimento científico". Essa troca, essa umbigada, conquistada em nossas andanças em campos de pesquisa, tem possibilitado aos integrantes da Companhia formação mais ampla em várias áreas de conhecimento profissional. Como recebemos pessoas de diversos cursos da UFRJ, esse pensar tem-se multiplicado, e, a cada encontro, podemos sentir que somos eternos aprendizes perante o universo da cultura popular.

Mestre Dado continua:

Não teve lugar melhor do que ter ido no Encontro com Mestres, no Rio de Janeiro. Agora vocês aqui que ajudaram a gente para conseguir o Barracão. Eu já

7 Com a verba do Prêmio Mestre Duda os batuqueiros conseguiram reformar o espaço do quintal da casa do Mestre e comprar um aparelho de DVD e uma televisão. vinha falando, lá trás, da vontade que eu tinha de fazer alguma coisa aqui no meu quintal, pra gente reunir, conversar... ${ }^{7}$ tinha que ter um espaço nosso. O Rio de Janeiro abriu a nossa cabeça. Agora vai ter bastante criança aqui, tenho certeza. Vou para a escola, vou para tudo que é lugar para conversar com esse povo aí. Ensinar a eles. Fazer oficina para eles aqui. Botar o vídeo lá e explicar o porquê. 
Moro aqui no Parque Piracicaba, há 27 anos, e ninguém sabia que eu era do batuque. Assim fosse todo fim de semana, esses meninos todos aqui em casa, para abrir isso aqui. Isso daqui para mim está muito bom demais. Vocês não sabem como é bom vocês aqui, e a vizinhança estar vendo a casa cheia de gente. Sempre gostei e vivi no meio do batuque. É o único lugar que quando a gente está chateado, você ouve um barulho e você pode ir, dá risada e a sua mente... Estou aqui conversando com vocês e estou me lembrando dos amigos batuqueiros que partiram, que podiam estar aqui do lado, conversando... Eu me emocionei, me desculpem. Todo mundo tem direito de se emocionar. $\mathrm{O}$ que vocês fizeram por mim foi tudo de bom. Muito obrigado.

Será que ele e todo o grupo podem imaginar o que aquilo tudo estava sendo para nós da UFRJ? Mestre Dado avisou: "Na festa de inauguração do Barracão, o couro vai comer. Firma as pernas, que nós vamos dançar muito." E assim foi... Fogueira pronta, tambores esticando no fogo. Muitos tipos de carne numa superchurrasqueira, a cerveja rolando, e a cachaça nativa, para os tambores e para todos. E foi chegando gente, de dois a 92 anos, todos participando de alguma forma, mesmo que apenas sorrindo. Nós, antigos e recentes integrantes da Companhia Folclórica do Rio-UFRJ e da vida, além das funções de pesquisadores, éramos também anfitriões, por termos ajudado nos preparativos e de tão integrados que já estávamos com os donos da casa. Todos muito emocionados, também, por estar ali participando daquela comemoração de outros e nossa. A performance começa com uma roda de todos os presentes para rezar o Pai Nosso. "Eu peço proteção, peço para tudo dar certo, então eu acho que o batuque tem religião. A minha religião é o meu batalhão", afirmou Mestre Dado, em entrevista anterior. E toda aquela construção histórica, artística, identitária e muito divertida começa e recomeça, como que para sempre.

Este texto é o primeiro documento produzido sobre essa experiência tão intensa. A primeira umbigada dos dois. Outras virão, com mais aprofundamento teórico e detalhamento de figurinos, linhas melódicas e rítmicas, coreografia e muitas outras histórias vividas.

$\mathrm{O}$ que mais me encantou foi a mistura. De repente, o novo e o velho se complementam, o negro e o branco viram arco-íris, ninguém é pobre ou rico, e todos sorriem e chamam, um ao outro, para o mistério. Mistério do corpo, de encontrar e celebrar o ritmo, a diferença, a herança, os ancestres, a alegria de estar vivendo aquele momento. Uma gratificante sensação de sentir que um projeto universitário pode, em festa, colaborar com a valorização dessas pessoas que criam e persistem em manter, apesar de todas as dificuldades, nossa cultura popular, nosso patrimônio. Precisamos incrementar políticas públicas em defesa desta nossa riqueza nacional e seus criadores. Essa pode ser uma grande colaboração das universidades à sociedade de que fazem parte. A UFRJ está comemorando o desenvolvimento de um Programa de Arte e Cultura, no qual a Companhia Folclórica do Rio-UFRJ está organizando ações oficializadas para a cultura popular, com apoio da Secretaria de Identidade e Diversidade Cultural do Ministério da Cultura. 
A festa em Piracicaba durou o dia inteiro, mas, na memória de quem a viveu, ela é eterna! Mestre Dado e Deusa Minerva brincaram e brincarão para sempre, numa bem firmada umbigada. Viva essa parceria!

O apito toca, e está na hora de partir. Para isso, puxo uma moda que, como outras, foi inspirada em diversas motivações e histórias. Essa, todo mundo conhece, é só imaginar em batuque de umbigada.

\section{Al AI AI AI / TÁ CHEGANDO A HORA / O DIA JÁ VEM RAIANDO MEU BEM / EU TENHO QUE IR EMBORA}

Mestre Dado, provavelmente, diria "Muuito bom!".

\section{REFERÊNCIAS BIBLIOGRÁFICAS}

BARBOSA, Wallace de Deus e TEIXEIRA, Carlo Alexandre. O ritual como linguagem performática: tempo, improvisação e regimes de visibilidade. In Poièsis: Estudos de Ciência da Arte, n.2. Publicação do mestrado em Ciência da Arte-UFF. Niterói: Madgráfica, 2000, p.117-128.

CARNEIRO, Edison. Negros bantos: notas de etnografia religiosa e de folclore. Rio de Janeiro/Brasília: Civilização Brasileira/INL, 1981.

CASCUDO, Luís da Câmara. Cultura e sociedade: pesquisas e notas de etnografia geral. Belo Horizonte: Itatiaia, 1983.

. Made in África. São Paulo: Global, 2001.

DIAS, Paulo. A outra festa negra. In: Cultura \& sociabilidade na América portuguesa. São Paulo: Edusp, 2001.

DUVIGNAUD, Jean. Sociologia da arte. Rio de Janeiro: Forense, 1970.

FRADE, Cascia. Universidade e cultura popular. Textos Escolhidos de Cultura e Arte Populares. Rio de Janeiro, v.3, n.1, p. 7-15, 2006.

FRIGERIO, Alejandro. Artes negras: uma perspectiva afrocêntrica. O percevejo: revista de teatro, crítica e estética. Rio de Janeiro, ano II, n.12, 2003, p.51-67.

HUIZINGA, Johan. Homo ludens: o jogo como elemento da cultura. São Paulo: Perspectiva, 2001.

MONTEIRO, Noedi. www. piracicaba.sp.gov.br, visitado em 2 de maio de 2008.

RODRIGUES, Graziela. O bailarino-pesquisador-intérprete: processo de formação. Rio de Janeiro: Funarte, 1997.

TINHORÃO, José Ramos. Os sons dos negros no Brasil. São Paulo: Editora 34, 2008.

Eleonora Gabriel é mestre em Ciência da Arte-UFF, professora adjunta da UFRJ, responsável pelas disciplinas sobre danças e folguedos folclóricos, EEFD e coordenadora do projeto acadêmico Companhia Folclórica do Rio-UFRJ. 